\title{
Fluid Shear Stress Induces Endothelial Transforming Growth Factor Beta-1 Transcription and Production Modulation by Potassium Channel Blockade
}

\author{
Minoru Ohno, John P. Cooke, Victor J. Dzau, and Gary H. Gibbons \\ Division of Cardiovascular Medicine, Stanford University School of Medicine, Stanford, California 94305
}

\begin{abstract}
The endothelium has the capacity to modulate vascular structure in response to hemodynamic stimuli. We tested the hypothesis that exposure of the endothelium to increased laminar shear stress induces the expression of TGFB1 via a signal transduction pathway modulated by $\mathrm{K}^{+}$channel currents. Although TGF $\beta 1$ is normally secreted in a latent, inactive form, exposure of cultured endothelial cells to steady laminar shear stress $\left(20\right.$ dynes $\left./ \mathrm{cm}^{2}\right)$ induced increased generation of biologically active TGF $\beta 1$. This increase in active TGF $\beta 1$ was associated with a sustained increase in TGF $\beta 1$ mRNA expression within $2 \mathrm{~h}$ of stimulation. TGF $\beta 1$ mRNA levels increased in direct proportion to the intensity of the shear stress within the physiologic range. The effect of shear stress on TGFB1 mRNA expression was regulated at the transcriptional level as defined by nuclear run-off studies and transient transfection of a TGFB1 promoter-reporter gene construct. Blockade of endothelial $\mathbf{K}^{+}$ channels with tetraethylammonium significantly inhibited: activation of TGF $\beta 1$ gene transcription; increase in steady state mRNA levels; and generation of active TGF $\beta 1$ in response to shear stress. These data suggest that endothelial $\mathrm{K}^{+}$channels and autocrine-paracrine TGF $\beta 1$ may be involved in the mechanotransduction mechanisms mediating flow-induced vascular remodeling. (J. Clin. Invest. 1995. 95:1363-1369.) Key words: flow - mechanical stress $\bullet$ cytokine $\cdot$ ion channel $\cdot$ gene expression
\end{abstract}

\section{Introduction}

A large body of evidence indicates that hemodynamic stimuli have profound effects on vascular function and structure (1). For example, blood vessels undergo a dramatic remodeling process to increase lumen diameter in response to the chronically high flow state created by an arterio-venous fistula or an intracardiac shunt (2). Conversely, a chronic decrease in flow induces a structural decrease in lumen diameter (3). Studies by Langille and O'Donnell (3) indicate that the endothelium plays a critical role as the blood vessel's mechanotransducer, mediating the effect of these chronic changes in flow or shear stress

Address correspondence to Gary H. Gibbons, Falk Cardiovascular Research Center, 300 Pasteur Drive, Stanford, CA 94305-5246.

Received for publication 30 August 1993 and in revised form 12 December 1993.

J. Clin. Invest.

(c) The American Society for Clinical Investigation, Inc.

0021-9738/95/03/1363/07 \$2.00

Volume 95, March 1995, 1363-1369 (the tractive force created by fluid flow) on vascular architecture. Chronic changes in blood flow also modulate the process of vascular lesion formation in diseases such as atherosclerosis, vein graft stenosis, and restenosis after angioplasty (4-6). Kraiss et al. (6) have recently shown that modest increases in shear stress within the physiologic range inhibit neointimal hyperplasia after vascular injury. These data indicate that, in response to increased shear stress, the endothelium expresses a potent paracrine factor that inhibits vascular smooth muscle cell proliferation in vivo. The inhibitory factor that mediates this response remains to be defined. In the present study we tested the hypothesis that exposure of endothelial cells to increased laminar shear stress induces the expression of $\operatorname{TGF} \beta 1$, a pleiotropic factor that inhibits vascular smooth muscle cell growth $(7,8)$.

The precise molecular mechanisms by which the endothelium senses changes in shear stress and promotes vascular remodeling in accordance with hemodynamic stimuli remain to be further characterized. Electrophysiologic studies indicate that the endothelium senses changes in shear stress via the activation of $\mathrm{K}^{+}$channels that result in membrane hyperpolarization and changes in intracellular calcium (9-14). We have previously reported that flow-activated $\mathrm{K}^{+}$channels appear to play an important signal transduction role in the shear stress-stimulated generation of nitric oxide by the endothelium $(15,16)$. These data suggest that shear stress may induce changes in endothelial cell function via a mechanotransduction pathway involving changes in $\mathrm{K}^{+}$and $\mathrm{Ca}^{2+}$ ion currents. Our working hypothesis is that: $(a) \mathrm{TGF} \beta 1$ may be a mediator of flow-induced vascular remodeling, and $(b)$ endothelial cell $\mathrm{K}^{+}$channels may modulate shear stress-induced changes in endothelial cell gene expression regulation.

\section{Methods}

\section{Cell culture}

Bovine aortic endothelial cells (BAEC) ${ }^{1}$ were harvested and passaged by trypsinization as previously described (16). These cells have been characterized as endothelial cells based upon morphology, acetylatedLDL binding, angiotensin-converting enzyme measurements, and Factor VIII antigen analysis. The cells were grown on tissue culture plates ( 150 $\mathrm{cm}^{2}$ ) in $10 \%$ calf serum in DME/F12 supplemented with L-glutamine (4 $\mathrm{mM})$, Hepes buffer $\mathrm{pH} 7.4$, penicillin $(100 \mathrm{U} / \mathrm{ml})$, and streptomycin $(100 \mu \mathrm{g} / \mathrm{ml})$. Studies were conducted on cells between passages 4 and 11 that were maintained at a confluent state for $2 \mathrm{~d}$. Before exposure to shear stress, the medium was switched to a defined serum-free medium without ATP, that contains insulin $(1 \mu \mathrm{M})$, transferrin $(5 \mathrm{mg} / \mathrm{ml})$, and ascorbate $(0.2 \mathrm{mM})$.

1. Abbreviations used in this paper. BAEC, bovine aortic endothelial cells; CAT, chloramphenicol acetyltransferase; SSRE, shear stress responsive element; TEA, tetraethylammonium. 


\section{Shear stress apparatus}

We have constructed a shear stress apparatus that enables us to expose a large population of cultured endothelial cells to steady laminar shear stress within a well-defined physiologic range. Our system is modified from the original cone-plate viscometer design characterized by Bussolari and Dewey and has been previously described (16-18). Briefly, the rotating cone forms a $0.5^{\circ}$ angle with the $150-\mathrm{cm}^{2}$ tissue culture dish containing cultured BAEC. The angular velocity of the cone is precisely adjusted by the motor controller to expose the cells to physiologic levels of laminar shear stress ranging from 0 to 40 dynes $/ \mathrm{cm}^{2}$ as calculated by previously described formulae $(17,18)$. The average value for the shear stress exerted on the BAEC was determined by computing the magnitude of shear stress at increasing radii beginning in the center of the dish to $4.5 \mathrm{~cm}$, integrating that value over that range of radii, and dividing by the total surface area of the cell population. Although the magnitude of the shear stress varies with the radius of the dish, the variance in shear stress across the dish was minimal (variance $\leq 10 \%$ of mean shear stress) within the range of shear stresses studied. To maximize uniformity in the exposure of cells to shear stress and to avoid the effect of flow fields that deviate significantly from laminar conditions at the edge of the plate (17), the analysis was limited to cells grown within a $4.5-\mathrm{cm}$ radius of the dish. Previous studies have documented that cells undergo flow-stimulated alignment and remain viable in this medium over a $24-\mathrm{h}$ period based on morphology, trypan blue exclusion, lactate dehydrogenase assay, and protein synthesis measurements.

\section{TGF $\beta$ bioassay}

Mink lung epithelial cells (CCL-64; American Type Culture Collection, Rockville, MD) have been used as a very sensitive bioassay for the growth inhibitory effects of the active form of $\operatorname{TGF} \beta 1$ as previously described (18). Subconfluent cells were incubated with purified TGF $\beta 1$ or endothelial cell-conditioned medium. DNA synthesis was measured by pulsing with $\left[{ }^{3} \mathrm{H}\right]$ thymidine $(2 \mu \mathrm{Ci} / \mathrm{ml})$ for a 4-h period beginning $20 \mathrm{~h}$ after agonist stimulation and by assaying trichloroacetic acidprecipitable counts. The growth of these cells was not influenced by incubation with the potassium channel blocker tetraethylammonium (TEA) ion at the concentrations employed in this study (data not shown). A standard curve was constructed for each assay using purified human TGF $\beta 1$ (R\&D Systems, Inc., Minneapolis, MN). Conditioned medium was obtained from endothelial cells and administered to mink lung epithelial cells in varying dilutions $(1: 10-1: 80)$, which provided values within the linear range of the standard curve. The specificity of the inhibitory response was confirmed by blockade with specific antiTGF $\beta 1$ neutralizing antibodies. Comparisons were made between control rabbit or chicken IgG (Sigma Chemical Co., St. Louis, MO) and a purified IgG fraction of either rabbit or chicken polyclonal anti-TGF $\beta 1$ neutralizing antibody (TGFAB; R\&D Systems, Inc.). This anti-TGF $\beta 1$ antibody does not cross-react with either acidic or basic fibroblast growth factor, platelet-derived growth factor, or epidermal growth factor (manufacturer's data). The antibody recognizes the active but not the latent form of $\operatorname{TGF} \beta 1$, inhibits specific $\operatorname{TGF} \beta 1$ binding to its surface receptor, immunoprecipitates TGF $\beta 1$ at a $1: 10,000$ dilution, and has been extensively characterized in biological systems in our laboratory and others $(8,18-22)$.

\section{TGF $\beta 1$ mRNA analysis}

RNA was isolated from BAEC using the guanidium isothiocyanate and cesium chloride gradient methods. TGF $\beta 1$ mRNA expression was assessed by Northern blot or quantitated by slot-blot analysis by standard techniques (23). The RNA was electrophoresed in a $1.5 \%$ agarose and $2.2 \mathrm{M}$ formaldehyde gel, immobilized to a nitrocellulose filter, and hybridized by standard techniques. A ${ }^{32} \mathrm{P}$-random-labeled 747-bp fragment of the porcine TGF $\beta 1$-specific cDNA probe was used for hybridization (kindly provided by Dr. Michael Sporn, National Cancer Institute, Bethesda, MD). After hybridization, the membrane was washed with $2 \times$ SSC and $0.1 \%$ SDS at room temperature for $30 \mathrm{~min}$, with
$0.2 \times$ SSC and $0.5 \%$ SDS at $60^{\circ} \mathrm{C}$ for $1.5 \mathrm{~h}$, and autoradiography was performed. In slot-blotting analysis, three different amounts of RNA (4, 8 , and $16 \mu \mathrm{g}$ ) were blotted on a nitrocellulose filter in a slot-blot apparatus, and hybridization was performed as described for Northern blotting. The intensity of the signal produced by probe hybridization was analyzed by densitometry. To control for variability of loading of RNA, ethidium bromide staining of the gel for ribosomal RNA was routinely assessed and confirmed by rehybridization and autoradiography with a ${ }^{32} \mathrm{P}$-end-labeled oligonucleotide for human $28 \mathrm{~S}$ ribosomal RNA (Clontech Laboratories, Inc., Palo Alto, CA). Uniformity of RNA loading in the slot-blot was confirmed by the linearity of the hybridization to increasing quantities of total RNA as well as by rehybridization with the $28 \mathrm{~S}$ ribosomal RNA probe. A negative hybridization control in the slot-blot analysis was provided by loading the blot with transfer RNA.

\section{Nuclear run-off assay}

This assay was performed based on the method of Gutenberg as described (24). The nuclear extract of BAEC was harvested $2 \mathrm{~h}$ after shear stress stimulation $\left(20 \pm 2\right.$ dynes $\left./ \mathrm{cm}^{2}\right)$ and incubated with the reaction buffer (Tris- $\mathrm{HCl} \mathrm{pH} 8.0,10 \mathrm{mM} \mathrm{MgCl}_{2}, 5 \mathrm{mM} \mathrm{KCl}$, and $300 \mathrm{mM}$ ATP, CTP, GTP, with $\left.0.5 \mathrm{mM}\left[{ }^{32} \mathrm{P}\right] \mathrm{UTP}[6,000 \mathrm{Ci} / \mathrm{mM}][100 \mu \mathrm{Ci}]\right)$ for $30 \mathrm{~min}$ at $30^{\circ} \mathrm{C}$. The supernatant was extracted twice by phenol/ chloroform and nascent RNA bound to a nitro-cellulose filter. Newly transcribed RNA was removed from the filter and resuspended in hybridization buffer at equal counts per min per $\mathrm{ml}\left(5 \times 10^{5} \mathrm{cpm} / \mathrm{ml}\right)$. Either the TGF $\beta 1$ or the control human GAPDH cDNA plasmid (American Type Culture Collection) was used as a probe. The linearized plasmid was slot-blotted on nitrocellulose filters, hybridized, washed, and autoradiographed by standard techniques.

\section{TGF $\beta 1$ promoter-reporter gene transfection and $C A T$} assay

The human TGF $\beta 1$ promoter-chloramphenicol acetyltransferase (CAT) chimeric plasmid constructs containing the promoter region -453 to +11 (a gift from Dr. Kim and Dr. Sporn) have been previously characterized (25). Previous studies have established that this reporter gene construct and the endogenous gene exhibit similar patterns of expression in a wide variety of cell lines $(25,26)$. The present study confirms this observation with respect to shear stress stimulation and phorbol ester stimulation in BAEC (see Results). The TGF $\beta 1$-CAT construct (20 $\mu \mathrm{g}$ ) was co-transfected with the SV40 luciferase gene expression vector $(10 \mu \mathrm{g})$ (Promega Biotec, Madison, WI) into BAEC by the calcium phosphate method as previously described (27). As an additional control, BAEC were transfected with a CAT expression vector under control of a Rous sarcoma virus promoter to assess nonspecific effects of shear stress stimulation on CAT activity. BAEC in defined serum-free medium were either: $(a)$ subjected to shear stress $\left(20 \pm 2\right.$ dynes $/ \mathrm{cm}^{2}$ for $\left.8 \mathrm{~h}\right)$; $(b)$ maintained under static conditions; or $(c)$ stimulated with PMA $(100 \mathrm{ng} / \mathrm{ml})$. Cell extracts were harvested at $48 \mathrm{~h}$ after transfection, and CAT activity was quantitated by the thin-layer chromatography method as previously described (27). Luciferase activity was measured by luminometer using standard methods (Promega Biotec). CAT activity was normalized by luciferase activity as a control for variation in transfection efficiency.

\section{Experimental protocols}

Active TGF $\beta 1$ production. BAEC were subjected to steady laminar shear stress $\left(20 \pm 2\right.$ dynes $\left./ \mathrm{cm}^{2}\right)$ or static conditions for $24 \mathrm{~h}$. Conditioned medium from the endothelial cells was harvested at varying time points within this $24-\mathrm{h}$ period, and active TGF $\beta 1$ was measured by the bioassay as described above. Pilot studies documented maximal accumulation of active TGF $\beta 1$ at $24 \mathrm{~h}$.

TGF 1 I mRNA expression. (a) RNA was isolated from either shear stress-stimulated culture dishes or static controls for Northern blotting at $0,2,4,8$, and $12 \mathrm{~h}$ after exposure to laminar shear stress $(20 \pm 2$ dynes $/ \mathrm{cm}^{2}$ ). Pilot time control studies established that constitutive TGF $\beta 1$ mRNA expression remains constant during this 12 -h period. (b) To determine the relationship between shear stress intensity (at 5 , 
$10,20,30$, and 40 dynes $/ \mathrm{cm}^{2}$ ) and TGF $\beta 1 \mathrm{mRNA}$ levels, quantitative analysis by slot-blotting was performed with RNA harvested at the 4$\mathrm{h}$ time point. ( $c$ ) To further define the role of transcriptional regulation in the shear stress-induced increase in TGF $\beta 1$ mRNA levels, we initially examined the effect of pretreatment with the transcription inhibitor actinomycin $\mathrm{D}\left(10^{-6} \mathrm{M}\right)$. Similarly, to assess the role of de novo protein synthesis in the induction of TGF $\beta 1$, BAEC were pretreated with cycloheximide $(20 \mu \mathrm{g} / \mathrm{ml})$. In addition, nuclear run-off experiments were performed to assess changes in TGF $\beta 1$ gene transcription rates, and these were compared to GAPDH gene transcription rates. We have confirmed previous reports that endothelial cell expression of GAPDH is not modified by shear stress stimulation (28). Furthermore, the effect of shear stress ( 20 dynes $/ \mathrm{cm}^{2}$ ) on TGF $\beta 1$ gene transcription was assessed by transfection of the TGF $\beta 1$ promoter-CAT gene constructs and by the measurement of CAT activity compared to static controls.

Effect of $\mathrm{K}^{+}$channel blockade. Previous studies have established that TEA at $3 \mathrm{mM}$ specifically and effectively blocks $\mathrm{K}^{+}$ion channels in several cell types including endothelial cells $(29-31)$. We have previously shown that TEA blocks flow-induced vasodilation and the release of nitric oxide by the endothelium but has no effect on agoniststimulated nitric oxide production via $\mathrm{K}^{+}$channel-independent signal transduction pathways $(15,16)$. To block endothelial $\mathrm{K}^{+}$channels, the cells were pretreated with TEA $(3 \mathrm{mM})$ for $30 \mathrm{~min}$ and then exposed to shear stress ( 20 dynes $/ \mathrm{cm}^{2}$ ) and compared to vehicle-treated controls. The effect of TEA on TGF $\beta 1$ expression was assessed at the protein. RNA, and DNA transcription levels. (a) TGF $\beta 1$ activity: Conditioned medium derived from BAEC exposed to shear stress in the presence of TEA $3 \mathrm{mM}$ or vehicle for $24 \mathrm{~h}$ was collected and assayed for the active form of TGF $\beta 1$ by the bioassay. Pilot experiments documented that TEA within the conditioned medium had no effect on mink lung epithelial cell growth. (b) TGF $\beta 1$ mRNA expression: RNA was harvested after a 6$\mathrm{h}$ exposure to shear stress $\left(20 \pm 2\right.$ dynes $\left./ \mathrm{cm}^{2}\right)$ in the presence or absence of TEA $(3 \mathrm{mM})$. The specificity of the effect of TEA was confirmed by inducing TGF $\beta 1 \mathrm{mRNA}$ expression with PMA treatment ( $100 \mathrm{ng} /$ $\mathrm{ml}$ ) in the presence of TEA compared to vehicle. Furthermore, the effect of the ATP-sensitive $\mathrm{K}^{+}$channel blocker glybenclamide $\left(10^{-5} \mathrm{M}\right)$ on flow-induced TGF $\beta 1$ expression was also assessed as an additional control. ( $c$ ) TGF $\beta 1$ gene transcription: Finally, the effect of TEA treatment on the induction of CAT activity in response to shear stress (20 2 dynes $/ \mathrm{cm}^{2}$ ) was determined in BAEC transfected with the TGF $\beta 1$ promoter-CAT reporter gene and compared to static controls and PMAtreated cells.

All experimental results were verified by replication at least three times. Data are presented as the mean \pm SEM. Statistical analysis was performed with either ANOVA followed by Dunnet's test for multiple comparisons or Student's $t$ test where appropriate. A $P$ value $<0.05$ was considered statistically significant.

\section{Results}

Expression of biologically active TGF $\beta$. The control of TGF $\beta$ expression involves both transcriptional and posttranslational regulatory mechanisms. The conversion of latent to active TGF $\beta$ is a critical step in determining its biological effects. We have confirmed previous reports that the predominant form of TGF $\beta 1$ generated by cultured BAEC is the latent biologically inactive molecule. However, in response to steady laminar shear stress $\left(20 \pm 2\right.$ dynes $\left./ \mathrm{cm}^{2}\right)$, endothelial cells produced a 4-10fold increase in the generation of the active form of $\operatorname{TGF} \beta 1$ (Fig. 1). Abolition of this growth-inhibitory activity in the bioassay by the specific anti-TGF $\beta 1$ neutralizing antibody verified that active TGF $\beta$ was generated in response to shear stress.

TGF $\beta 1$ mRNA expression. To assess whether the increased production of active TGF $\beta 1$ resulted from increased mRNA levels versus increased conversion of latent to active $\operatorname{TGF} \beta 1$, we examined the effect of shear stress on TGF $\beta 1$ mRNA ex-

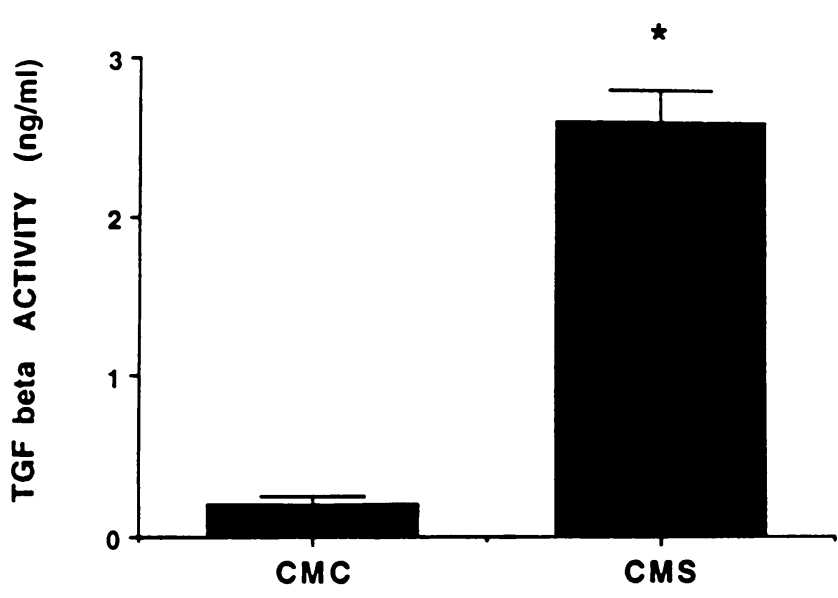

Figure 1. TGF $\beta$ activity in conditioned medium from BAEC exposed to steady laminar shear stress. Conditioned medium was collected from BAEC exposed to either $20 \pm 2$ dynes $/ \mathrm{cm}^{2}$ or static conditions for $24 \mathrm{~h}$, and the effect on mink lung epithelial cell thymidine incorporation was assessed. These experiments were repeated three times with similar results. $C M C$, conditioned medium collected from cells exposed to 0 dynes $/ \mathrm{cm}^{2}$. $C M S$, conditioned medium collected from cells exposed to 20 dynes $/ \mathrm{cm}^{2}$.

pression. As assessed by Northern blot, confluent BAEC expressed modest levels of TGF $\beta 1$ mRNA constitutively. Exposure of endothelial cells to steady laminar shear stress of $20 \pm 2$ dynes $/ \mathrm{cm}^{2}$ induced a three- to fivefold increase in TGF $\beta 1$ mRNA levels within $2 \mathrm{~h}$ of exposure and a sustained elevation of expression for over $12 \mathrm{~h}$ compared to static controls (Fig. 2 ). Low levels of shear stress $\left(<5 \mathrm{dynes} / \mathrm{cm}^{2}\right)$ failed to induce significant increases in steady state TGF $\beta 1$ mRNA levels. However, at levels of mean shear stress beyond this threshold, the increase in TGF $\beta 1 \mathrm{mRNA}$ levels was directly proportional to the intensity of the shear stress within the physiologic range of $5-40$ dynes $/ \mathrm{cm}^{2}$ as determined by quantitative slot-blot analysis (Fig. 3). This flow-induced increase in TGF $\beta 1$ mRNA expression could be blocked by the transcription inhibitor actinomycin D but not by the inhibition of de novo protein synthesis with cycloheximide (data not shown).

To further characterize whether the effect of shear stress on TGF $\beta 1$ mRNA expression was regulated at the level of gene transcription, nuclear run-off experiments were performed. These experiments confirmed that shear stress induced a threeto fivefold increase in the rate of transcription of the TGF $\beta 1$ gene, whereas the transcription rate of the GAPDH gene was unaffected by shear stress stimulation (Fig. 4). Similarly, BAEC transfected with the TGF $\beta 1$ promoter-CAT construct and exposed to shear stress $\left(20 \pm 2\right.$ dynes $\left./ \mathrm{cm}^{2}\right)$ expressed threefold higher levels of CAT activity than the static controls (see Fig. 7). Hence, several lines of evidence indicate that the induction of increased CAT activity in response to shear stress reflects specific activation of the $\operatorname{TGF} \beta 1$ promoter and enhanced TGF $\beta 1$ gene transcription.

Effect of potassium channel blockade. Based on previous electrophysiologic evidence that shear stress activates an endothelial cell $\mathrm{K}^{+}$current, we examined the effect of $\mathrm{K}^{+}$channel blockade with TEA on TGF $\beta 1$ expression at the protein, RNA, and DNA levels. The administration of TEA markedly attenuated the production of biologically active TGF $\beta$ in response to shear stress as determined by bioassay $(P<0.01)$ (Fig. 5 ). 


\section{Northern blotting}

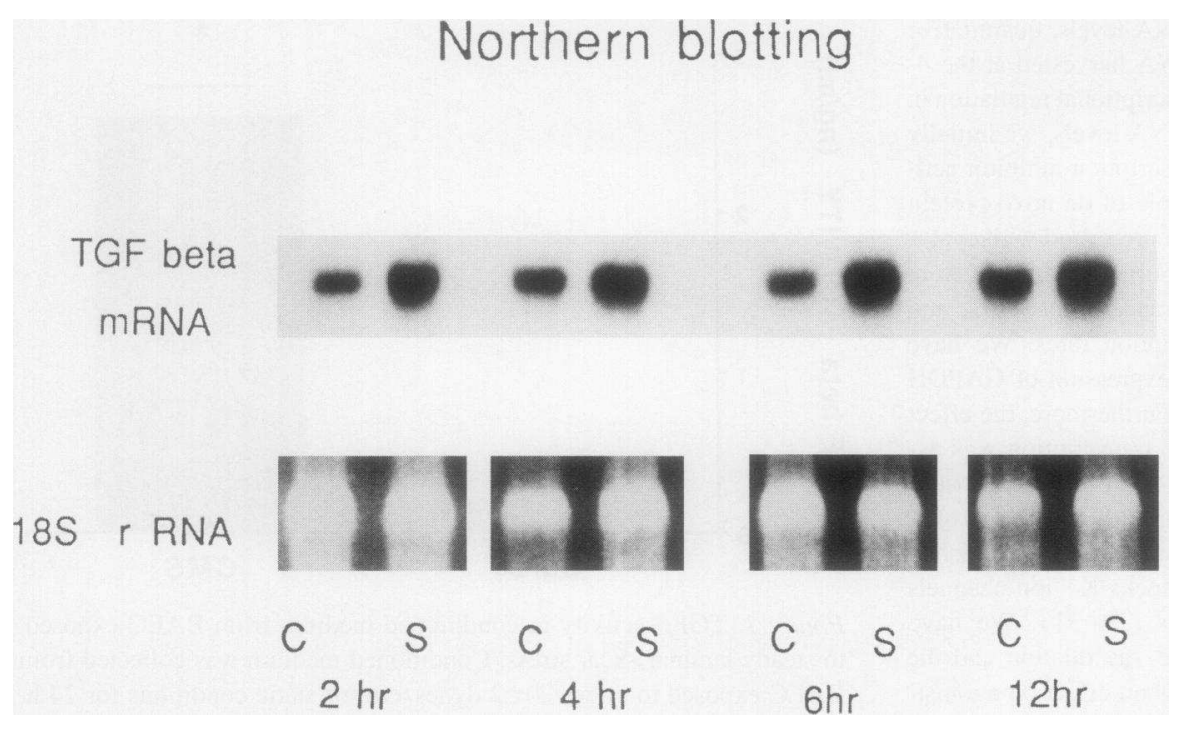

Figure 2. Induction of TGF $\beta 1 \mathrm{mRNA}$ expression by exposure to shear stress. Total RNA was harvested from BAEC exposed to $20 \pm 2$ dynes $/ \mathrm{cm}^{2}$ and compared to static controls harvested at the same time. TGF $\beta 1$ mRNA expression was assessed by Northern blot (30 $\mu \mathrm{g} /$ lane) (upper lanes). The blot was rehybridized with a $28 \mathrm{~S}$ ribosomal RNA probe as an internal control that is unaffected by shear stress.
In accordance with the protein data, the shear stress-induced increase in TGF $\beta 1$ mRNA levels was also significantly inhibited by TEA $(P<0.01)$ (Fig. 6). The specificity of this response is further evidenced by the observation that the ATPsensitive $\mathrm{K}^{+}$channel blocker glybenclamide had no effect on the shear stress-induced TGF $\beta 1$ mRNA expression (data not shown). Furthermore, the selectivity of the effect of TEA is verified by the finding that TEA had no significant effect on either basal (vehicle $=1.0 \pm 0.1 \mathrm{U}$ vs TEA treated $=1.1 \pm 0.2$ $\mathrm{U} ; P>0.05$ ) or phorbol ester-stimulated TGF $\beta 1$ mRNA expression $($ vehicle $=3.5 \pm 0.4 \mathrm{U}$ vs TEA treated $=3.6 \pm 0.4 \mathrm{U}$; $P>0.05$ ).

Finally, to define the signal transduction link between $\mathrm{K}^{+}$ channel currents and the activation of TGF $\beta 1$ gene transcription, BAEC transfected with the TGF $\beta 1$ promoter-CAT construct were examined. As shown in Fig. 7, blockade of $\mathrm{K}^{+}$

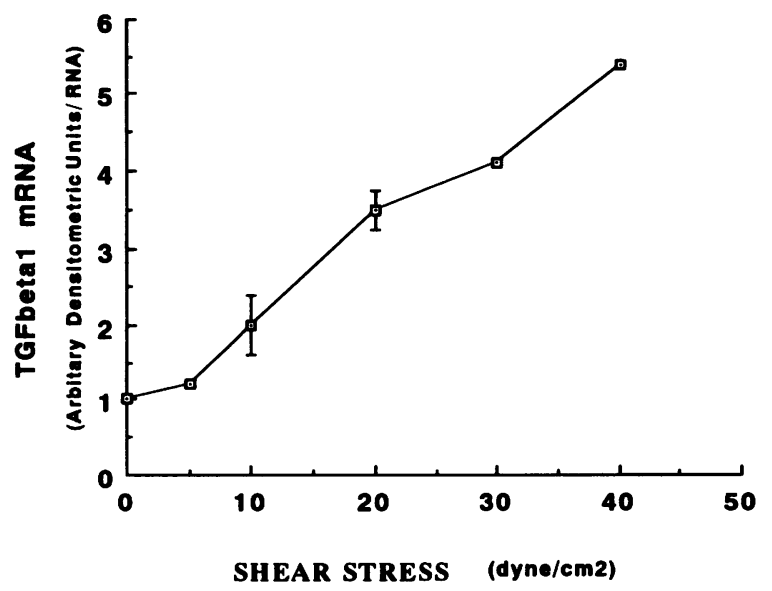

Figure 3. Stimulus-response relationship between shear stress and TGF $\beta 1$ mRNA levels. TGF $\beta 1$ mRNA levels were assessed after a 4-h exposure to shear stress by slot-blot. The hybridization signal was quantified by densitometry and normalized by hybridization to the $28 \mathrm{~S}$ ribosomal RNA level. Data are expressed as a ratio of TGF $\beta 1$ mRNA levels after exposure to shear stress relative to the TGF $\beta 1 \mathrm{mRNA}$ level in the static control. The figure shows a representative experiment that was replicated three times. channels significantly attenuated the increase in CAT activity induced by shear stress. In contrast, the induction of CAT activity stimulated by phorbol ester treatment was not inhibited by TEA.

\section{Discussion}

A large body of evidence indicates that chronic changes in blood flow are important determinants of vascular structure (26,32 ). It is postulated that this process of flow-induced vascular remodeling is mediated by the flow-stimulated expression of endothelium-derived autocrine-paracrine growth factors. Using in vitro model systems, our laboratory and others have documented increased mRNA expression of the mitogen PDGF B chain in response to increased laminar shear stress $(18,33)$. However, it is noteworthy that the effect of shear stress on PDGF mRNA levels is relatively transient, and that generation of the biologically active protein product in endothelial cellconditioned medium has not yet been demonstrated. Indeed, in preliminary experiments we observed that conditioned medium derived from BAEC exposed to shear stress inhibits aortic vascular smooth muscle cell proliferation (unpublished observation). In accordance with this observation, Morigi et al. have recently reported similar effects on mesangial cell growth (34). Based on previous studies documenting the inhibitory effect of TGF $\beta 1$ on vascular smooth muscle cell growth, we tested the

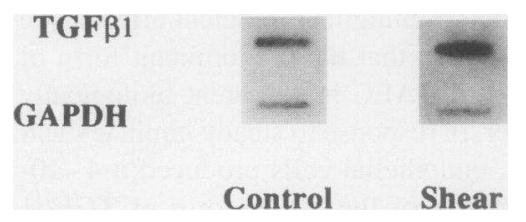

Figure 4. Shear stress induces an increased rate of TGF $\beta 1$ gene transcription. Nuclear extracts were harvested from BAEC exposed to shear stress $(20 \pm 2$

dynes $/ \mathrm{cm}^{2}$ ) for $2 \mathrm{~h}$ compared to static controls. The transcription rate of the TGF $\beta 1$ gene vs GAPDH was assessed by nuclear run-off assay. There was no significant hybridization to the linearized plasmid vector without the cDNA insert (data not shown). As shown in the upper lanes, exposure to shear stress induced an increase in the transcription of the endogenous TGF $\beta 1$ gene in BAEC, whereas there was no effect on GAPDH gene transcription (lower lanes). 


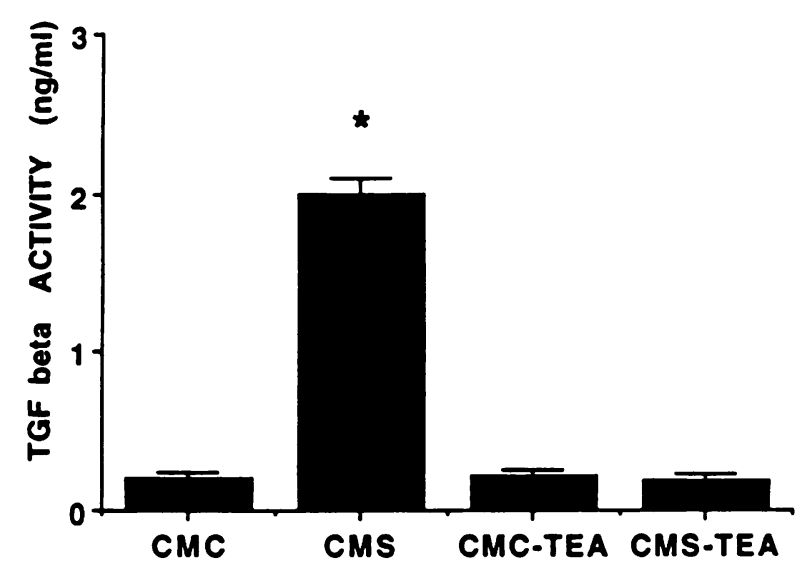

Figure 5. The effect of $\mathrm{K}^{+}$channel blockade with TEA on shear stressinduced production of active TGF $\beta$. BAEC pretreated with either TEA $(3 \mathrm{mM})$ or vehicle were exposed to shear stress $\left(20 \pm 2 \mathrm{dynes} / \mathrm{cm}^{2}\right)$ or maintained under static conditions for $24 \mathrm{~h}$. BAEC-conditioned medium was harvested at $24 \mathrm{~h}$ and TGF $\beta$ activity was assessed by the mink lung epithelial cell bioassay. $C M C$, conditioned medium from vehicletreated static control BAEC. $C M S$, conditioned medium from vehicletreated cells exposed to shear stress. CMC-TEA, conditioned medium from TEA-treated BAEC under static conditions in the presence of TEA $3 \mathrm{mM}$. CMS-TEA, conditioned medium from BAEC exposed to shear stress in the presence of TEA $3 \mathrm{mM}$. *Significant difference between both CMC vs CMS and CMS and SMS-TEA at $P<0.05$.

hypothesis that TGF $\beta 1$ may be the predominant paracrine growth factor generated by the endothelium in response to laminar shear stress.

TGF $\beta 1$ is normally secreted by endothelial cells in a latent, inactive form unless stimulated by coculture with smooth muscle cells (22). Our study indicates that exposure to increased shear stress activates a mechanism by which endothelial cells are able to convert the latent TGF $\beta 1$ to its biologically active form. The mechanisms governing this response remain to be further defined. Based upon previous evidence that shear stress induces increased expression of tissue plasminogen activator (tPA) (35) and that plasmin can promote the conversion of

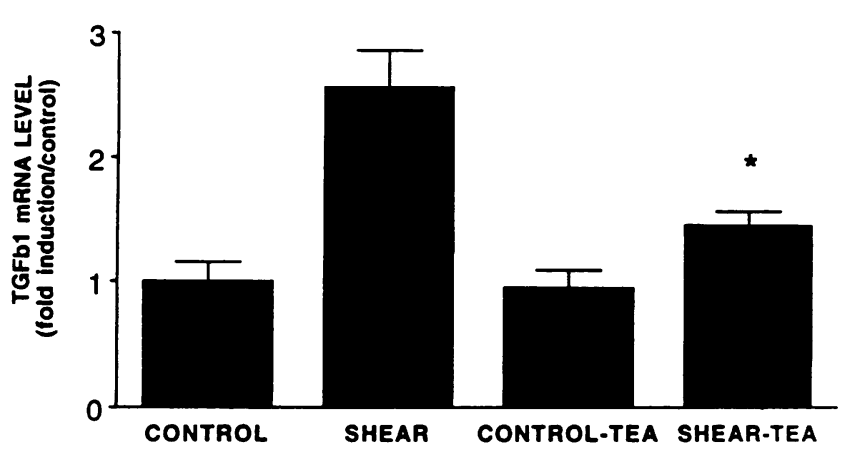

Figure 6. The effect of TEA on shear stress-induced TGF $\beta 1 \mathrm{mRNA}$ expression. Total RNA was harvested from BAEC under static conditions or exposed to shear stress $\left(20 \pm 2\right.$ dynes $\left./ \mathrm{cm}^{2}\right)$ for $4 \mathrm{~h}$. The levels of TGF $\beta 1$ mRNA were quantitated by slot-blot using densitometry and normalized by the constitutive expression of $28 \mathrm{~S}$ ribosomal RNA. The induction of TGF $\beta 1$ mRNA expression in response to shear stress is graphically presented as the increase relative to the static control (control $=1.0$ densitometric units). ${ }^{*}$ Significant difference between shear vs shear-TEA at $P<0.05$.

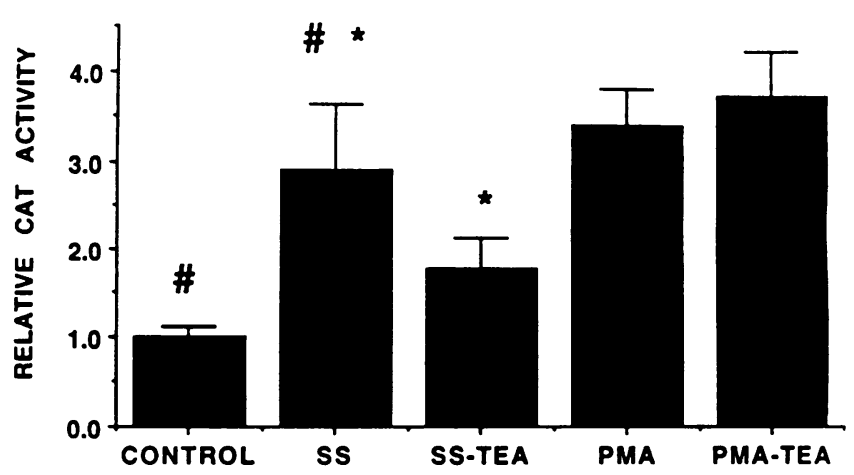

Figure 7. The effect of $\mathrm{K}^{+}$channel blockade on the regulation of TGF $\beta 1$ gene transcription. BAEC were transiently transfected with the TGF $\beta 1$ promoter-CAT construct $(-453$ to $+11 \mathrm{bp})(20 \mu \mathrm{g})$ and a luciferase gene construct $(10 \mu \mathrm{g})$ driven by the SV40 promoter and exposed to shear stress $\left(20 \pm 2\right.$ dynes $\left./ \mathrm{cm}^{2}\right)$ for $8 \mathrm{~h}$ or maintained under static conditions in the presence or absence of TEA ( $3 \mathrm{mM})$. The induction of CAT activity in response to shear stress is graphically represented as the relative increase compared to the vehicle-treated static control (control $=1.0$ unit). Control, vehicle-treated static control. SS, vehicletreated BAEC exposed to shear stress. PMA, phorbol ester treated BAEC ( $100 \mathrm{ng} / \mathrm{ml})$. PMA-TEA, TEA-treated PMA-stimulated control. SS-TEA, TEA-treated BAEC exposed to shear stress. *Statistically significant differences between SS vs control and SS-TEA vs SS respectively at $P$ $<0.05$.

latent to active $\operatorname{TGF} \beta$ (22), we speculate that the coexpression of TGF $\beta 1$ and tPA may mediate the increased generation of active $\mathrm{TGF} \beta 1$ in response to shear stress.

In addition to these posttranslational mechanisms, shear stress promotes increased production of active TGF $\beta 1$ via the induction of increased TGF $\beta 1$ mRNA expression. Indeed, the rise in steady state TGF $\beta 1 \mathrm{mRNA}$ levels is directly proportional to the level of shear stress within the range of shear stresses typically observed in vivo. The lack of effect of cycloheximide on the induction of TGF $\beta 1$ suggests that de novo synthesis of a transcription factor is not essential for TGF $\beta 1$ transcription in response to shear stress. Our finding that shear stress regulates TGF $\beta 1$ gene expression at the transcriptional level was clearly demonstrated by both the nuclear run-off experiments and the TGF $\beta 1$ promoter-CAT construct transfection studies.

Electrophysiologic studies have documented that exposure to increased shear stress activates endothelial cell $\mathrm{K}^{+}$channels, induces hyperpolarization, and promotes calcium influx (914). Based upon our previous observation that the shear stressinduced release of nitric oxide is modulated by flow-activated $\mathrm{K}^{+}$channels $(15,16)$, we hypothesized that this mechanotransduction pathway may also play a role in the regulation of flowstimulated endothelial cell gene expression. Indeed, blockade of endothelial cell $\mathrm{K}^{+}$channels with TEA significantly inhibited the shear stress-induced increase in TGF $\beta 1$ gene transcription. However, we observed no effect from the ATP-sensitive $\mathrm{K}^{+}$ channel blocker glybenclamide, and in preliminary studies we have been unable to block the induction with the calcium-activated $\mathrm{K}^{+}$channel blocker charybdotoxin. The precise nature of the TEA-inhibitable $\mathrm{K}^{+}$channel currents remains to be further defined. We speculate that the mechanotransduction of shear stress-induced changes in endothelial function involves an interplay between the regulation of $\mathrm{K}^{+}$and $\mathrm{Ca}^{2+}$ currents in which $\mathrm{K}^{+}$channel-induced hyperpolarization may promote $\mathrm{Ca}^{2+}$ in- 
flux and activate $\mathrm{Ca}^{2+}$-dependent kinases and other signaling mechanisms. This study provides intriguing evidence of a novel mechanotransduction pathway linking shear stress, $\mathrm{K}^{+}$channel currents, and the induction of endothelial cell gene transcription. The precise nature of the TEA-inhibited $\mathrm{K}^{+}$channels, the interaction between $\mathrm{K}^{+}$currents and $\mathrm{Ca}^{2+}$ fluxes, and the coupling mechanisms between these ionic currents and the cis and trans elements involved in TGF $\beta 1$ gene expression regulation remain to be further defined.

During the preparation of this manuscript, Resnick et al. (36) reported that the induction of PDGF B chain gene expression in response to shear stress is associated with nuclear binding to a previously undefined cis element. As we and others have previously shown, the effect of shear stress on PDGF B mRNA levels is transient and biphasic (28). In contrast, TGF $\beta 1$ mRNA levels increase rapidly and remain elevated above basal levels for a sustained period. We speculate that there are significant differences in the mechanisms regulating shear stressstimulated gene expression of PDGF B compared to TGF $\beta 1$. A sequence that is complementary to the putative shear stress responsive element (SSRE) described within the PDGF B chain promoter is present at position -1219 in the human TGF $\beta 1$ promoter. However, our preliminary deletion analysis indicates that this putative regulatory sequence has no significant influence on the induction of TGF $\beta 1$ gene expression in response to shear stress. Indeed, as documented in this study, we have localized a SSRE within the TGF $\beta 1$ promoter in a region between -453 and +11 that does not contain the putative PDGF $B$ chain SSRE or its complementary sequence. We therefore speculate that the effect of shear stress on TGF $\beta 1$ gene transcription is mediated via novel SSRE cis and trans elements that are modulated by $\mathrm{K}^{+}$channel activity. Additional studies are necessary to further characterize these cis and trans regulatory elements involved in modulating the expression of various genes induced by shear stress.

In summary, this study has characterized the effect of shear stress on the regulation of TGF $\beta 1$ expression at the DNA, RNA, and protein levels. Moreover, we have further defined a novel mechanotransduction pathway in which endothelial $\mathrm{K}^{+}$channel currents appear to modulate the activation of TGF $\beta 1$ gene transcription in response to shear stress. Given the profound effect of TGF $\beta 1$ on vascular cell growth, migration, and extracellular matrix production, our findings provide potential new insights into the molecular mechanisms governing flow-induced vascular remodeling.

\section{Acknowledgments}

The authors wish to acknowledge the technical assistance of Frederick Lopez, Zeren Yang, and Wendy Lee, as well as the secretarial assistance of Joan Rosel. We are grateful to Adel Malek for his invaluable contributions to the design of the shear stress apparatus and for useful discussions.

This work was supported by National Institutes of Health grants HL-02660, HL-35252, and HL-48638; a California Affiliate Grant-inAid 91-136; the Tobacco-related Disease Research Program of the University of California 3KT-0375; an unrestricted gift from Bristol-Myers Squibb for cardiovascular research; the Beckman Center Director's Research Grant provided by Smith Kline Beecham; and grants from ParkeDavis and Syntex Research. Minoru Ohno is the recipient of a BristolMyers Squibb Japan-Stanford Cardiovascular Fellowship, John P. Cooke is the recipient of a National Institutes of Health Vascular Academic Award, and Gary H. Gibbons is an awardee of the Robert Wood
Johnson Foundation Minority Faculty Development Fellowship Program.

\section{References}

1. Rubanyi, G. M., A. D. Freany, K. Kauser, A. Johns, and D. R. Harder. 1990. Mechanoreception by the endothelium: mediators and mechanisms of pressure- and flow-induced vascular response. Blood Vessels. 27:246-257.

2. Kamiya, A., and T. Togawa. 1980. Adaptive regulation of wall shear stress to flow change in the canine carotid artery. Am. J. Physiol. 239:H14-H21.

3. Langille, B. L., and F. O'Donnell. 1986. Reductions in arterial diameter produced by chronic decreases in blood flow are endothelium-dependent. Science (Wash. DC). 231:405-407.

4. Glagov, S., C. Zarins, D. P. Giddens, D. Ku, and N. Ku. 1988. Hemodynamics and atherosclerosis: insights and perspectives gained from studies of human arteries. Arch. Pathol. Lab. Med. 112:1018-1031.

5. Faulkner, S. L., R. D. Fisher, D. M. Conkle, D. L. Page, and H. W. Bender 1975. Effect of blood flow rate on subendothelial proliferation in venous autografts used as arterial substitutes. Circulation. 51/52 (Suppl. I):I-163-I-172.

6. Kraiss, L. W., T. R. Kirkman, T. R. Kohler, B. Zierler, and A. W. Clowes. 1991. Shear stress regulates smooth muscle proliferation and neointimal thickening in porous polytetrafluoroethylene grafts. Arterioscler. Thromb. 11:18441852.

7. Owens, G. K., A. A. T. Geisterfer, Y. W.-H. Yang, and A. Komoriya. 1988. Transforming growth factor- $\beta$-induced growth inhibition and cellular hypertrophy in cultured vascular smooth muscle cells. J. Cell Biol. 107:771-780.

8. Gibbons, G. H., R. E. Pratt, and V. J. Dzau. 1992. Vascular smooth muscle cell hypertrophy vs. hyperplasia: autocrine transforming growth factor- $\beta 1$ expression determines growth response to angiotensin II. J. Clin. Invest. 90:456461.

9. Olesen, S. P., D. E. Clapham, and P. F. Davies. 1988. Hemodynamic shear stress activates a $\mathrm{K}^{+}$current in vascular endothelial cells. Nature (Lond.). 331:168-170.

10. Mo, M., S. G. Eskin, and W. P. Schilling. 1991. Flow-induced changes in $\mathrm{Ca}^{2+}$ signaling of vascular endothelial cells. Am. J. Physiol. 260:H1698-1707.

11. Dull, R. O., and P. F. Davies. 1991. Flow modulation agonist (ATP)response $\left(\mathrm{Ca}^{2+}\right)$ coupling of vascular endothelial cells. Am. J. Physiol. 261:H149154.

12. Shen, J., F. W. Luscinskas, A. Connoly, C. F. Dewey, and M. A. Gimbrone, Jr. 1992. Fluid shear stress modulates cytosolic free calcium in vascular endothelial cells. Am. J. Physiol. 262:C384-C390.

13. Nakache, M., and H. E. Gaub. 1988. Hydrodynamic hyperpolarization of endothelial cells. Proc. Natl. Acad. Sci. USA. 85:1841-1843.

14. Luckhoff, A., and R. Busse. 1990. Calcium influx into endothelial cells and formation of EDRF is controlled by the membrane potential. Pflueg. Arch. Eur. J. Physiol. 416:305-311.

15. Cooke, J. P., E. Rossitch, Jr., N. A. Andon, J. Loscalzo, and V. J. Dzau. 1991. Flow activates an endothelial potassium channel to release an endogenous nitrovasodilator. J. Clin. Invest. 88:1663-1671.

16. Ohno, M., G. H. Gibbons, V. J. Dzau, and J. P. Cooke. 1993. Shear stress elevates endothelial cGMP: role of a potassium channel and G protein coupling. Circulation. 88:193-197.

17. Bussolari, S. R., C. F. Dewey, and M. A. Gimbrone, Jr. 1982. Apparatus for subjecting living cells to fluid shear stress. Rev. Sci. Instrum. 53:1851-1854.

18. Danielpour, D., D. Dart, K. C. Flanders, A. B. Roberts, and M. B. Sporn. 1989. Immunodetection and quantitation of the two forms of transforming growth factor beta (TGF- $\beta 1$ and TGF- $\beta 2$ ) secreted by cells in culture. J. Cell Physiol. 138:79-86.

19. Keski-Oja, J., R. M. Lyons, and H. L. Moses. 1987. Immunodetection and modulation of cellular growth with antibodies against native transforming growth factor-beta. Cancer Res. 47:6451-6458.

20. Antonelli-Orlidge, A., K. B. Saunders, S. R. Smith, and P. A. D̀Amore. 1989. An activated form of transforming growth factor beta is produced by cocultures of endothelial cells and pericytes. Proc. Natl. Acad. Sci. USA. 86:45444548 .

21. McCaffrey, T. A., D. J. Falcone, C. F. Brayton, L. A. Agarwal, F. G. P. Welt, and B. B. Weksler. 1989. Transforming growth factor- $\beta$ activity is potentiated by heparin via dissociation of the transforming growth factor- $\beta / \alpha_{2}$-macroglobulin inactive complex. J. Cell Biol. 109:441-448.

22. Sato, Y., and D. B. Rifkin. 1989. Inhibition of endothelial cell movement by pericytes and smooth muscle cells: activation of a latent transforming growth factor- $\beta 1$-like molecule by plasmin during co-culture. J. Cell Biol. 109:309315

23. Sambrook, J., E. F. Fritsch, and T. Maniatis. 1993. Molecular Cloning: A Laboratory Manual. Cold Spring Harbor Laboratory, Cold Spring Harbor, NY. $73-78$.

24. Ausbel, F. M., R. Roger, R. E. Kingston, D. D. Moore, J. G. Seideman, J. A. Smith, and K. Struhl. 1991. Current Protocols of Molecular Biology. John Wiley \& Sons Inc., New York. 4.10.1-4.10.11. 
25. Kim, S.-J., A. Glick, M. B. Sporn, and A. B. Roberts. 1989. Characterization of the promoter region of the human transforming growth factor-betal gene. J. Biol. Chem. 264:402-408.

26. Geiser A. G., S.-J. Kim, A. B. Roberts, and M. B. Sporn. 1991. Characterization of the mouse transforming growth factor-betal promoter and activation by the Ha-ras oncogene. Mol. Cell. Biol. 11:84-92.

27. Barrett, G., M. Horiuchi, M. Paul, R. E. Pratt, N. Nakamura, and V. J. Dzau. 1992. Identification of a negative regulatory element involved in tissuespecific expression of mouse renin genes. Proc. Natl. Acad. Sci. USA. 89:885889.

28. Malek, A. M., G. H. Gibbons, V. J. Dzau, and S. Izumo. 1993. Fluid shear stress differentially modulates expression of genes encoding basic fibroblast growth factor and platelet-derived growth factor B chain in vascular endothelium. J. Clin. Invest. 92:2013-2021.

29. Cook, N. S. 1988. The pharmacology of potassium channels and their therapeutic potential. Trends in Pharmacol. Sci. 9:21-28.

30. Chen, G., and D. W. Cheung. 1992. Characterization of acetylcholineinduced membrane hyperpolarization in endothelial cells. Circ. Res. 70:257-263.
31. Rusko, J., F. Tanzi, C. van Breemen, and D. J. Adams. 1992. Calciumactivated potassium channels in native endothelial cells from rabbit aorta: conductance, $\mathrm{Ca}^{2+}$ sensitivity, and block. J. Physiol. (Camb.). 455:601-621.

32. Gibson, C. M., L. Diaz, K. Kandarpa, F. M. Sacks, R. C. Pasternak, T. Sandor, C. Felman, and P. H. Stone. 1993. Relation of vessel wall shear stress to atherosclerosis progression in human coronary arteries. Arterioscler. Thromb. 13:310-315.

33. Hsieh, H., N. Li, and J. A. Frangos. 1991. Shear stress increases endothelial platelet-derived growth factor mRNA levels. Am. J. Physiol. 260:H642-H646.

34. Morigi, M., C. Zoja, M. Figliuzzi, G. Remuzzi, and A. Remuzzi. 1993. Supernatant of endothelial cells exposed to laminar flow inhibits mesangial cell proliferation. Am. J. Physiol. 264:C1080-C1083.

35. Diamond, S. L., S. G. Eskin, and L. V. McIntire. 1989. Fluid flow stimulates tissue plasminogen activator secretion by cultured human endothelial cell. Science (Wash. DC). 243:1483-1485.

36. Resnick, N., T. Collins, W. Atkinson, D. T. Bonthron, C. F. Dewey, and M. A. Gimbrone. 1993. Platelet-derived growth factor B chain promoter contains a cis-acting fluid shear-stress-responsive element. Proc. Natl. Acad. Sci. USA. 90:4591-4595. 